\title{
RAPD reveals genetic similarity of Acer saccharum and Acer nigrum
}

\author{
ADAM P. SKEPNER \& DAN E. KRANE* \\ Department of Biological Sciences, Wright State University, Dayton, OH 45435-0001, U.S.A.
}

\begin{abstract}
The number of species and subspecies that comprise North American sugar maples has remained in dispute since their first characterization over 100 years ago. The distinction between Acer nigrum (black maples) and Acer saccharum (sugar maples) in particular has been controversial. Despite readily distinguished morphologies and different adaptive advantages, these trees hybridize readily and their ranges extensively overlap. Extensive RAPD-PCR based analyses of $A$. nigrum and $A$. saccharum trees collected from throughout their range reveal that they are genetically distinguishable only on a geographical basis and not by their morphologies. The extent to which locally collected, indigenous trees displaying the characteristic $A$. nigrum and $A$. saccharum morphologies are genetically indistinct, seriously undermines the basis for assigning distinguishing species names to these trees. The distinctive characteristics of these trees may be affected by a relatively small set of genes or may even constitute inducible responses on the part of trees to their local environments.
\end{abstract}

Keywords: Acer nigrum, Acer saccharum, biodiversity, black maple, genetic variability, sugar maple.

\section{Introduction}

Sugar maple (Acer saccharum) is important commercially for its wood and sugar sap and also for its ornamental value. Previous genetic studies (see Kriebel \& Gabriel, 1969, for a review) concerned primarily with obtaining high sugar sap content and superior wood quality, suggest that sugar maple may actually be a group comprising several species or subspecies (A. saccharum, A. nigrum, A. floridanum and $A$. grandidentatum).

The assignment of the nigrum (black maples) designation has historically been the most controversial. In stands where black maple and sugar maple grow alone both have readily distinguished morphologies. The bark of black maples is characteristically more deeply furrowed and darker in colour than that of other sugar maples. Black maples are further distinguished by their three-lobed leaves which stand in sharp contrast to the five-lobed leaves of sugar maples. However, the ranges of $A$. nigrum (from western Iowa to western Pennsylvania) and $A$. saccharum (from eastern Iowa to New England) overlap extensively and hybrids are abundant.

Authors of some tree guides recognize $A$. nigrum and $A$. saccharum as separate species (reviewed by Little, 1979) whereas other authors consider black maples to be a subspecies (Burns \& Honkala, 1990; Dirr, 1990). Numerous studies (e.g. Dansereau \& Desmarais, 1947; Desmarais, 1952; Kriebel, 1957)

*Correspondence. E-mail: dkrane@wright.edu have been unable to resolve this issue. Kriebel (1957), for example, recognized the subspecies designation out of convention but insisted that a final answer regarding the taxonomy of the trees could only come with further study. More recently, Graves has both recognized the subspecies designation (Graves, 1994a) and treated the trees as separate species in another study of the responses of the two morphologies to drought (Graves, 1994b).

Much of the disagreement regarding the appropriate taxonomic assignment of sugar and black

Table 1 Collection sites and tree morphologies of Acer nigrum and $A$. saccharum used for RAPD analysis

\begin{tabular}{lcc}
\hline & $\begin{array}{c}\text { Number of } \\
\text { individuals } \\
\text { sampled }\end{array}$ & $\begin{array}{c}\text { Morphology } \\
\text { type } \\
\text { nigrum/ } \\
\text { saccharum }\end{array}$ \\
Sample collection site & 4 & $2 / 2$ \\
\hline $\begin{array}{l}\text { University of Minnesota } \\
\quad \text { St. Paul, MN }\end{array}$ & 4 & $0 / 4$ \\
$\begin{array}{l}\text { Pennsylvania State University } \\
\quad \text { University Park, PA }\end{array}$ & 5 & $5 / 0$ \\
$\begin{array}{l}\text { University of Iowa Ames, IA } \\
\text { Ivory Tech College }\end{array}$ & 3 & $0 / 3$ \\
$\quad$ Richmond, IN & 1 & $0 / 1$ \\
$\begin{array}{l}\text { Cambridge, IN } \\
\text { Missouri Botanical Gardens } \\
\quad \text { St. Louis, MO }\end{array}$ & 2 & $1 / 1$ \\
$\quad$ Wright State University & 13 & $7 / 6$ \\
$\quad$ Dayton, OH & & \\
\hline
\end{tabular}




\begin{tabular}{|c|c|c|c|c|c|c|c|c|c|c|c|c|c|c|c|c|c|c|c|c|c|c|c|c|c|c|}
\hline & $\mathrm{BE}$ & $\mathrm{RM}$ & $\mathrm{AgM}$ & MN1 & MN2 & $m n 3$ & $m n 4$ & PA1 & PA2 & PA3 & PA4 & $i a 1$ & $i a 2$ & $i a 3$ & $i a 4$ & $i a 5$ & IN1 & IN2 & IN3 & IN4 & MO1 & mo2 & oh1 & oh2 & OH3 & $\mathrm{OH} 4$ \\
\hline $\mathrm{BE}$ & - & 41 & 32 & 36 & 37 & 41 & 35 & 25 & 29 & 34 & 31 & 30 & 31 & 27 & 36 & 27 & 29 & 31 & 31 & 30 & 26 & 28 & 26 & 34 & 32 & 30 \\
\hline RM & 0.66 & - & 33 & 48 & 46 & 49 & 43 & 28 & 34 & 38 & 37 & 38 & 41 & 30 & 34 & 36 & 34 & 33 & 32 & 34 & 36 & 32 & 32 & 33 & 40 & 35 \\
\hline $\mathrm{AgM}$ & 0.51 & 0.50 & - & 43 & 36 & 45 & 36 & 35 & 29 & 30 & 32 & 35 & 41 & 36 & 36 & 34 & 33 & 36 & 34 & 34 & 37 & 33 & 30 & 30 & 39 & 29 \\
\hline MN1 & 0.47 & 0.60 & 0.54 & - & 73 & 78 & 60 & 40 & 49 & 51 & 49 & 60 & 63 & 52 & 54 & 58 & 51 & 52 & 52 & 51 & 52 & 48 & 49 & 44 & 59 & 48 \\
\hline MN2 & 0.52 & 0.62 & 0.48 & 0.83 & - & 71 & 57 & 35 & 44 & 49 & 44 & 57 & 57 & 47 & 54 & 52 & 47 & 48 & 45 & 46 & 46 & 43 & 44 & 44 & 53 & 42 \\
\hline$m n 3$ & 0.54 & 0.61 & 0.56 & 0.83 & 0.80 & - & 68 & 41 & 48 & 53 & 48 & 59 & 60 & 48 & 57 & 51 & 48 & 49 & 48 & 45 & 46 & 44 & 48 & 50 & 54 & 43 \\
\hline mn4 & 0.53 & 0.62 & 0.52 & 0.72 & 0.73 & 0.81 & - & 35 & 41 & 44 & 40 & 49 & 47 & 41 & 48 & 43 & 41 & 43 & 37 & 36 & 41 & 40 & 37 & 38 & 41 & 35 \\
\hline PA1 & 0.40 & 0.42 & 0.53 & 0.50 & 0.47 & 0.51 & 0.50 & - & 44 & 43 & 46 & 35 & 35 & 35 & 37 & 36 & 31 & 30 & 27 & 31 & 35 & 32 & 31 & 30 & 31 & 28 \\
\hline PA2 & 0.46 & 0.51 & 0.43 & 0.61 & 0.58 & 0.59 & 0.58 & 0.66 & - & 42 & 41 & 39 & 38 & 34 & 37 & 36 & 39 & 36 & 32 & 30 & 38 & 35 & 33 & 35 & 35 & 35 \\
\hline PA3 & 0.49 & 0.52 & 0.41 & 0.59 & 0.60 & 0.61 & 0.58 & 0.59 & 0.57 & - & 56 & 38 & 39 & 30 & 44 & 39 & 35 & 38 & 34 & 32 & 36 & 33 & 37 & 34 & 39 & 34 \\
\hline PA4 & 0.47 & 0.53 & 0.46 & 0.59 & 0.56 & 0.57 & 0.54 & 0.66 & 0.58 & 0.73 & - & 37 & 38 & 35 & 40 & 37 & 37 & 35 & 33 & 29 & 38 & 34 & 36 & 33 & 38 & 35 \\
\hline ia1 & 0.45 & 0.55 & 0.5 & 0.72 & 0.73 & 0.71 & 0.67 & 0.50 & 0.55 & 0.50 & 0.50 & - & 61 & 55 & 49 & 49 & 41 & 43 & 39 & 40 & 40 & 35 & 40 & 38 & 43 & 40 \\
\hline$i a 2$ & 0.46 & 0.57 & 0.57 & 0.74 & 0.71 & 0.70 & 0.63 & 0.49 & 0.52 & 0.50 & 0.50 & 0.81 & - & 55 & 48 & 54 & 42 & 49 & 46 & 44 & 43 & 41 & 41 & 38 & 50 & 38 \\
\hline ia3 & 0.43 & 0.45 & 0.55 & 0.65 & 0.63 & 0.60 & 0.59 & 0.53 & 0.51 & 0.41 & 0.50 & 0.79 & 0.77 & - & 49 & 51 & 40 & 43 & 41 & 39 & 36 & 35 & 38 & 37 & 41 & 33 \\
\hline$i a 4$ & 0.52 & 0.47 & 0.50 & 0.63 & 0.67 & 0.66 & 0.63 & 0.51 & 0.50 & 0.56 & 0.52 & 0.64 & 0.62 & 0.68 & - & 57 & 43 & 47 & 44 & 46 & 39 & 34 & 41 & 44 & 44 & 36 \\
\hline$i a 5$ & 0.41 & 0.50 & 0.57 & 0.70 & 0.67 & 0.61 & 0.59 & 0.52 & 0.51 & 0.51 & 0.50 & 0.67 & 0.72 & 0.73 & 0.75 & - & 41 & 47 & 44 & 43 & 38 & 36 & 41 & 39 & 46 & 34 \\
\hline IN1 & 0.45 & 0.50 & 0.50 & 0.63 & 0.61 & 0.59 & 0.57 & 0.46 & 0.57 & 0.47 & 0.51 & 0.57 & 0.57 & 0.59 & 0.58 & 0.57 & - & 52 & 44 & 42 & 43 & 39 & 35 & 37 & 41 & 36 \\
\hline IN2 & 0.48 & 0.49 & 0.49 & 0.64 & 0.63 & 0.60 & 0.60 & 0.44 & 0.52 & 0.51 & 0.49 & 0.60 & 0.67 & 0.63 & 0.63 & 0.66 & 0.74 & - & 48 & 46 & 39 & 39 & 37 & 39 & 45 & 37 \\
\hline IN3 & 0.49 & 0.48 & 0.51 & 0.65 & 0.60 & 0.59 & 0.52 & 0.40 & 0.47 & 0.46 & 0.46 & 0.55 & 0.63 & 0.61 & 0.60 & 0.62 & 0.64 & 0.70 & - & 54 & 39 & 38 & 40 & 39 & 46 & 34 \\
\hline IN5 & 0.48 & 0.52 & 0.52 & 0.64 & 0.61 & 0.56 & 0.52 & 0.47 & 0.45 & 0.44 & 0.41 & 0.58 & 0.62 & 0.59 & 0.63 & 0.62 & 0.62 & 0.68 & 0.81 & - & 39 & 32 & 38 & 39 & 45 & 35 \\
\hline MO1 & 0.41 & 0.53 & 0.55 & 0.64 & 0.61 & 0.56 & 0.58 & 0.52 & 0.55 & 0.49 & 0.53 & 0.56 & 0.59 & 0.53 & 0.53 & 0.54 & 0.62 & 0.56 & 0.57 & 0.58 & - & 45 & 45 & 40 & 45 & 37 \\
\hline mo2 & 0.47 & 0.50 & 0.52 & 0.62 & 0.56 & 0.57 & 0.60 & 0.50 & 0.54 & 0.47 & 0.50 & 0.52 & 0.59 & 0.55 & 0.49 & 0.54 & 0.60 & 0.56 & 0.59 & 0.50 & 0.69 & - & 39 & 35 & 38 & 35 \\
\hline oh1 & 0.41 & 0.48 & 0.45 & 0.60 & 0.59 & 0.60 & 0.53 & 0.47 & 0.49 & 0.51 & 0.51 & 0.57 & 0.57 & 0.57 & 0.56 & 0.59 & 0.51 & 0.54 & 0.59 & 0.57 & 0.66 & 0.61 & - & 49 & 48 & 38 \\
\hline oh2 & 0.54 & 0.50 & 0.45 & 0.55 & 0.52 & 0.63 & 0.55 & 0.45 & 0.52 & 0.47 & 0.47 & 0.55 & 0.53 & 0.56 & 0.61 & 0.56 & 0.54 & 0.57 & 0.58 & 0.59 & 0.59 & 0.55 & 0.74 & - & 51 & 37 \\
\hline $\mathrm{OH} 3$ & 0.49 & 0.58 & 0.57 & 0.72 & 0.68 & 0.65 & 0.57 & 0.45 & 0.50 & 0.52 & 0.52 & 0.59 & 0.67 & 0.59 & 0.58 & 0.63 & 0.58 & 0.63 & 0.66 & 0.65 & 0.64 & 0.57 & 0.69 & 0.74 & - & 45 \\
\hline $\mathrm{OH} 4$ & 0.52 & 0.50 & 0.47 & 0.64 & 0.60 & 0.57 & 0.54 & 0.46 & 0.56 & 0.50 & 0.53 & 0.62 & 0.61 & 0.54 & 0.53 & 0.52 & 0.57 & 0.58 & 0.54 & 0.57 & 0.59 & 0.59 & 0.61 & 0.60 & 0.68 & - \\
\hline
\end{tabular}


maples may result from a lack of agreement between botanists as to what constitutes a species boundary. Traditionally, organisms that were unable to produce fertile offspring were considered to be members of different species (as described by Nei, 1987). Questions regarding what constitutes a biologically relevant barrier to gene flow, however, can complicate the assignment of species designations. Further, botanists have commonly made species designations on the basis of morphological differences regardless of naturally occurring hybridization. For example, members of the genus Quercus (the oaks) have poorly developed sterility barriers and cross readily (Grant, 1981). The white oaks of the eastern United States are grouped as members of 16 separate species, even though natural hybrids can be found wherever the ranges of the species overlap (Whittemore \& Schaal, 1991).

The extent to which the species boundaries

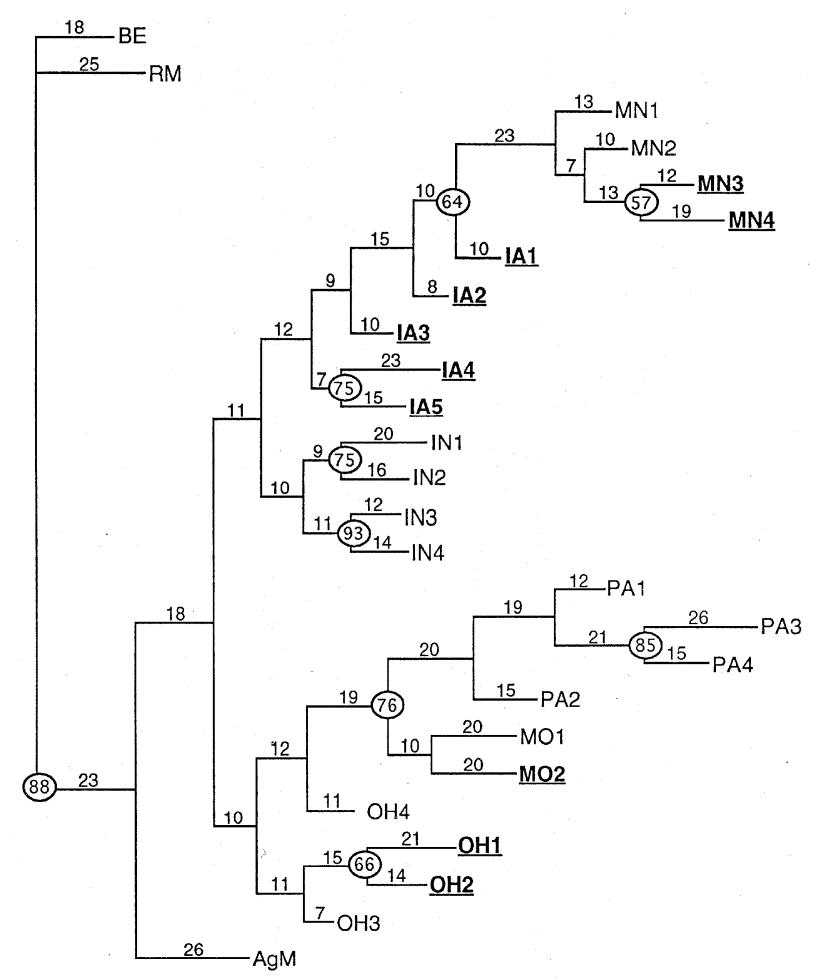

Fig. 1 Network of maximum parsimony for samples collected throughout the range of black and sugar maples. This is one of four equally parsimonious trees generated by PAUP (Swofford, 1991). Samples with the black maple morphology are underlined and shown in bold face. Branch lengths are shown on the horizontal lines of the tree. Numbers in ovals are bootstrap values that exceed 50 per cent (obtained after 5000 iterations). Names of individual organisms are the same as those described in Table 2 . appear to be violated in the white oaks has led to the concept of an 'ecological' species which differs from the traditional sense of the term (Solomon, 1983). From this perspective the oaks are able to hybridize because their different morphologies are the result of variation that results from adaptation or response to local environmental conditions and does not necessarily reflect an overall genetic distinctiveness of the populations.

Whittemore \& Schaal (1991) found that even ecological species such as oaks were accompanied by barriers to gene flow that resulted in the establishment of heritable and characteristic differences between populations. If the morphological types of maples are also members of distinct, ecological species, then the genomes of each morphology should harbour such differences as well.

Black and sugar maples might also represent an example of arrested speciation in progress. Glaciation in North America during the most recent ice age 35,000-10,000 years ago may have divided the ancestral ranges of maples (Desmarais, 1952). Subsequent retreat of the glaciers and recolonization by members of the two genetic pools could account for the contemporary distribution of black and sugar maples as well as their different morphologies.

Past studies on the speciation and evolutionary history of maples have been unable to draw firm conclusions because they considered only a small number $(<15)$ of morphological characters. More recent molecular studies involving maples have been concerned primarily with the conservation of sugar maple and did not distinguish between black and sugar maple morphologies (Foré et al., 1992a,b; Geburek, 1993; Young et al., 1993). A study that examines a larger number of characters, particularly ones not under direct selection, should be able to distinguish between the alternative classifications of black maples. Toward that end, we utilized RAPDPCR (Williams et al., 1990) to generate an array of over 380 anonymous polymorphic molecular markers for 15 black and 16 sugar maples, a 25 -fold increase in characters compared to previous studies.

\section{Materials and methods}

\section{Leaf collection}

Leaves were collected from seven widely separated North American sites (Table 1) spanning the sugar maple range. Only leaves from indigenous trees that exhibited either strong sugar or black maple morphologies (described in Desmarais, 1952) were selected. A minimum of five leaves were collected from each individual tree. Samples from a total of 
Table 3 Similarity matrix of RAPD data for the Dayton, OH black and sugar maple populations. Similarities of the samples are beneath the diagonal and the numbers of polymorphic bands shared by pairs of samples are above the diagonal. BM, black maple; SM, sugar maple; BE, box elder and RM, red maple. BM1, BM2, SM1 and SM2, respectively, correspond to $\mathrm{OH} 1, \mathrm{OH} 2, \mathrm{OH} 3$ and $\mathrm{OH} 4$ in Table 2

\begin{tabular}{lccccccccccccccc}
\hline & BM1 & BM2 & BM3 & BM4 & BM5 & BM6 & BM7 & SM1 & SM2 & SM3 & SM4 & SM5 & SM6 & BE & RM \\
\hline BM1 & - & 78 & 62 & 76 & 76 & 68 & 71 & 65 & 79 & 62 & 54 & 65 & 74 & 47 & 55 \\
BM2 & 0.75 & - & 54 & 70 & 64 & 63 & 67 & 60 & 61 & 68 & 60 & 60 & 62 & 40 & 37 \\
BM3 & 0.55 & 0.51 & - & 72 & 81 & 78 & 62 & 83 & 76 & 68 & 57 & 68 & 67 & 58 & 57 \\
BM4 & 0.66 & 0.65 & 0.63 & $\overline{-}$ & 83 & 78 & 73 & 77 & 75 & 73 & 71 & 84 & 77 & 58 & 57 \\
BM5 & 0.67 & 0.57 & 0.70 & 0.68 & $\overline{-}$ & 94 & 85 & 84 & 87 & 78 & 74 & 83 & 79 & 68 & 63 \\
BM6 & 0.58 & 0.57 & 0.67 & 0.65 & 0.76 & $\overline{-}$ & 74 & 85 & 81 & 77 & 68 & 79 & 83 & 67 & 64 \\
BM7 & 0.63 & 0.63 & 0.55 & 0.63 & 0.71 & 0.63 & $\overline{-}$ & 68 & 63 & 60 & 68 & 74 & 67 & 46 & 53 \\
SM1 & 0.57 & 0.56 & 0.73 & 0.66 & 0.70 & 0.72 & 0.59 & $\overline{-}$ & 92 & 78 & 72 & 75 & 73 & 67 & 55 \\
SM2 & 0.68 & 0.55 & 0.65 & 0.63 & 0.70 & 0.67 & 0.53 & 0.78 & $\overline{-}$ & 78 & 73 & 79 & 74 & 67 & 63 \\
SM3 & 0.57 & 0.66 & 0.62 & 0.65 & 0.67 & 0.68 & 0.54 & 0.70 & 0.68 & $\overline{-}$ & 83 & 80 & 72 & 52 & 52 \\
SM4 & 0.50 & 0.59 & 0.52 & 0.63 & 0.64 & 0.60 & 0.62 & 0.65 & 0.64 & 0.78 & $\overline{7}$ & 74 & 81 & 51 & 53 \\
SM5 & 0.58 & 0.56 & 0.59 & 0.71 & 0.68 & 0.66 & 0.64 & 0.65 & 0.66 & 0.71 & 0.66 & $\overline{1}$ & 88 & 61 & 63 \\
SM6 & 0.65 & 0.58 & 0.59 & 0.66 & 0.65 & 0.70 & 0.58 & 0.63 & 0.62 & 0.65 & 0.73 & 0.76 & - & 64 & 61 \\
BE & 0.44 & 0.40 & 0.55 & 0.51 & 0.60 & 0.61 & 0.43 & 0.62 & 0.61 & 0.50 & 0.50 & 0.56 & 0.59 & - & 65 \\
RM & 0.51 & 0.37 & 0.53 & 0.54 & 0.55 & 0.57 & 0.49 & 0.50 & 0.56 & 0.50 & 0.51 & 0.57 & 0.56 & 0.64 & - \\
\hline
\end{tabular}

23 individual maple trees (10 black and 13 sugar maples) were collected to examine variation throughout their ranges. Four of those individuals (two black and two sugar maples) were included with nine additional individuals (five black and four sugar maples) in a study of variation at a single collection site in Dayton, $\mathrm{OH}$.

Samples of box elder (Acer negundo) and red maple (Acer rubrum) were obtained locally from Wright State University, Dayton, $\mathrm{OH}$ and a silver maple (A. saccharinum) was collected from Cambridge, IN to serve as outgroups for this study.

\section{Extraction of total leaf DNA and RAPD analysis}

Total genomic leaf DNA was extracted from $10 \mathrm{mg}$ of leaf material by the method of Hamelin et al. (1993). The resulting pellets were washed with $70 \%$ ethanol, dried and resuspended in $50 \mu \mathrm{L}$ of $\mathrm{TE}$ [10 mм Tris ( $\mathrm{pH} 8.3$ ), $1 \mathrm{~mm}$ EDTA]. DNA samples were used immediately or stored at $-20^{\circ} \mathrm{C}$. Before use all DNA concentrations were estimated by gel electrophoresis and typically diluted 1:10 for RAPD analysis.

Table 4 Average pairwise similarity of RAPD profiles between trees with each of the morphologies used in this study

\begin{tabular}{lcc}
\hline Morphology & $\begin{array}{c}\text { Black maples } \\
\text { Average (SD) }\end{array}$ & $\begin{array}{c}\text { Sugar maples } \\
\text { Average (SD) }\end{array}$ \\
\hline Black maples & $0.637(0.07)$ & $0.625(0.06)$ \\
Sugar maples & - & $0.626(0.08)$ \\
Box elder & $0.512(0.08)$ & $0.551(0.05)$ \\
Red maple & $0.510(0.07)$ & $0.539(0.03)$ \\
\hline
\end{tabular}

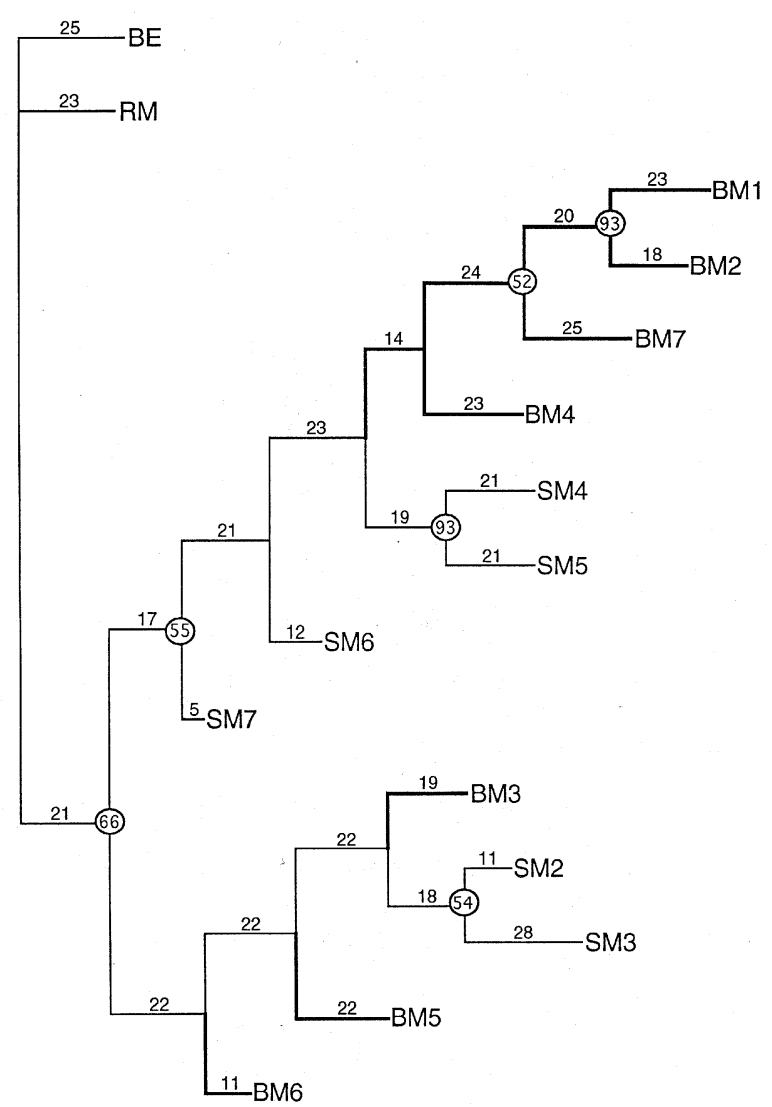

Fig. 2 Tree of maximum parsimony of Dayton, $\mathrm{OH}$ black (BM) and sugar (SM) maples. Branch lengths are listed on the horizontal lines. Numbers in ovals are those bootstrap values that exceed $50 \%$ (obtained after 5000 iterations). BE, box elder; RM, red maple. 
RAPD markers were amplified from total genomic leaf DNA as described by Williams et al. (1990). Final reaction volumes of $10 \mu \mathrm{L}$ containing $2 \mu \mathrm{L}$ of diluted genomic leaf DNA, 1.5 units of KT1 KlenTaq (Wayne Barnes, Washington University, St. Louis, MO), $20 \mathrm{~mm}$ Tris, $\mathrm{pH} 8.0,2.5 \mathrm{~mm}^{\mathrm{MgCl}_{2}}$, $16 \mathrm{~mm} \quad\left(\mathrm{NH}_{4}\right)_{2} \mathrm{SO}_{4}, \quad 150 \mu \mathrm{g} / \mathrm{mL}$ bovine serum albumin, $0.2 \mu \mathrm{m}$ of primer (Operon Technologies, Alameda, CA) and $60 \mu \mathrm{M}$ dNTP were found to generate DNA profiles from individual trees in a highly reproducible fashion (data not shown). A total of 13 primers (OPB-01 through OPB-03, OPB-05 through OPB-07, OPB-09 through OPB-14 and OPB-17) were used with templates from sugar and black maples collected throughout their ranges. A total of 19 additional primers (OPA-01 through OPA-18 and OPA-20) were used with templates from Ohio sugar and black maples.

MJ Research thermocyclers (PTC-100 and Minicycler models) were used for the amplifications, which consisted of 45 cycles of: $92^{\circ} \mathrm{C}$ for $1 \mathrm{~min}, 36^{\circ} \mathrm{C}$ for $1 \mathrm{~min}, 68^{\circ} \mathrm{C}$ for $2 \mathrm{~min}$. An additional extension at $68^{\circ} \mathrm{C}$ for $5 \mathrm{~min}$ followed the last round of amplification. Samples were stored at $4^{\circ} \mathrm{C}$ until RAPD analysed.

\section{Gel electrophoresis}

RAPD products were electrophoresed in $2 \%$ agarose gels in TBE buffer (10 mM TRIS, $\mathrm{pH} 8.3$, $10 \mathrm{~mm}$ boric acid, $1 \mathrm{~mm}$ EDTA). Gels were stained in ethidium bromide for $30 \mathrm{~min}$ and destained in water for $1 \mathrm{~h}$. Bands were visualized with a UV lamp and documented using a Gel Print 1000i imaging system (BioPhotonics Corp.).

\section{Data analysis}

Amplified bands were scored for their presence (1) or absence (0). Most RAPD profiles were scored at least twice independently and rare conflicts were resolved by a repeated amplification and scoring. The resulting tables were subjected to phylogenetic analysis using the heuristic search parameter of PAUP (Swofford, 1991). Pairwise comparisons between all the samples were also made and used to generate a similarity matrix with the following equation:

$f=2\left\{\frac{m_{x y}}{m_{x}+m_{y}}\right\}$,

where $m_{x y}$ is the number of bands any two samples share and $m_{x}$ and $m_{y}$ are the number of bands amplified in each sample (Clark \& Lanigan, 1993).
The resulting similarity matrix was analysed with the UPGMA clustering method of NTSYS-pc (Rohlf, 1994).

\section{Results}

Thirteen primers were used with genomic DNA isolated from black and sugar maples collected throughout their ranges and resulted in the amplification of 165 scorable polymorphisms. An average of 5.5 bands for each primer was obtained for each sample. The number of bands that any pair of samples shared (Table 2) was used to generate a pairwise similarity matrix (Table 2 ). No one band was found to distinguish uniquely all trees of one morphology from all trees of the other.

The outgroups box elder (BE), red maple (RM) and silver maple (AgM) were found to have an average similarity of $0.48 \quad\left(\sigma^{2}=0.05\right), \quad 0.53$ $\left(\sigma^{2}=0.06\right)$ and $0.51\left(\sigma^{2}=0.04\right)$, respectively, to the black maples included in this study and 0.47 $\left(\sigma^{2}=0.04\right), 0.52\left(\sigma^{2}=0.05\right)$ and $0.50\left(\sigma^{2}=0.05\right)$, respectively, to the sugar maples. The computer program PAUP (Swofford, 1991) was used with this data set to find four equally parsimonious trees (Fig. 1) that differ only in their grouping of the samples from Indiana and Iowa. These maximum parsimony trees confirm the outgroup status of $\mathrm{BE}$, RM and AgM (Burns \& Honkala, 1990) and group sugar and black maples in a fashion that was independent of morphology. In contrast, physical distance separating the collection sites of black and sugar maples used in this study was found to be negatively correlated with pairwise genetic similarity between the trees $\left(r^{2}=0.263, P<0.001\right)$. A UPGMAdendogram (data not shown) generated from the matrix in Table 2 further confirmed that the trees were grouped with other trees collected from geographically proximate sites but not in a fashion that was dependent on morphology.

RAPD reactions, using an additional 19 primers and total genomic DNA from seven black and six sugar maples obtained from a single collection site (Dayton, OH), were also performed to assess the distinctiveness of RAPD profile similarities of black and sugar maples where proximity of collection site was not a variable. These additional primers resulted in the amplification of 222 scorable bands of which 165 were found to be polymorphic within the black and sugar maple morphologies. An average of 5.4 bands was amplified with each primer of which an average of 3.8 bands was found to be polymorphic. The number of bands that any pair of samples shared (Table 3) was used to generate a pairwise similarity matrix (Table 3 ).

(c) The Genetical Society of Great Britain, Heredity, 80, 422-428. 
Analyses with these locally collected black and sugar maples again confirms the outgroup status of box elders (BE) and red maples (RM) (Burns \& Honkala, 1990). Further, the black and sugar maples again failed to resolve into separate clades in a UPGMA cluster analysis (data not shown). Pairwise similarity between trees with the black maple morphology was not significantly different $(P=0.47)$ from interclass similarity (Table 4). Sugar maples displayed marginally less intraclass similarity than that seen for black maples but were not significantly different $(P=0.49)$ from the average interclass similarity (Table 4).

Nondiagnostic characters (bands that were not present in at least two or more sugar or black maples) were excluded from the data, resulting in a simplified data matrix which was subjected to phylogenetic analysis using PAuP (Swofford, 1991). The single most parsimonious tree (Fig. 2) also failed to resolve black and sugar maples into separate clades.

The branches of the most parsimonious tree were manipulated using MacClade (Maddison \& Maddison, 1992) to create trees that separated black and sugar maples into separate clades. The most parsimonious tree that separated the two morphologies into discrete clades invoked 10 steps more than the tree of maximum parsimony (540 vs. 530).

\section{Discussion}

In both the traditional and ecological senses, the establishment of a new species is accompanied by the erection of barriers to the flow of genetic information between two populations. Over time, adaptation and genetic drift can give rise to characteristic differences between such populations at a genetic level. If black and sugar maples are separate species then cladistic analyses utilizing large numbers of polymorphic characters should detect such differences and allow trees with these morphologies to be resolved into two separate clades.

RAPD analyses afford an inexpensive and reliable means of assaying a virtually unlimited number of anonymous sites within bacterial, plant and animal genomes (Ferraris \& Palumbi, 1996, chapter 4). And, although questions have been raised regarding the suitability of RAPD analyses for phylogenetic comparisons involving distantly related organisms in which neutral substitutions are likely to be saturated, they have proven to be a particularly valuable tool for the consideration of closely related organisms (Clark \& Lanigan, 1993; Ferraris \& Palumbi, 1996, chapter 4). Further, RAPD and isozyme analyses have been found to produce very similar results in studies examining intraspecies variation in a variety of organisms such as black spruce (Isabel et al., 1995), cocoa plants (N'Goran et al., 1994) and Trypanosoma (Steindel et al., 1994).

Indeed, the RAPD profiles generated from the genomic DNA of black and sugar maples gave levels of genetic diversity $\left(\mu=0.567, \sigma^{2}=0.083\right.$ across their ranges and $\mu=0.625, \sigma^{2}=0.058$ for a local population) that are generally consistent with those reported by others using a variety of alternative methods (Perry \& Knowles, 1990; Foré et al., 1992b; Young et al., 1993; Simon et al., 1995). Further, analyses with RAPD profiles were able to detect differences in genetic similarity between trees that significantly correlated with the physical distance that separated their collection sites $(P<0.001)$. Previous analyses utilizing allozymes suggested that similar differences existed between sugar maples collected across southern Canada (Young et al., 1993) although these were not detected in studies from trees spanning smaller geographical ranges (Perry \& Knowles, 1990; Foré et al., 1992a).

Although parsimony (Fig. 1) and cluster analyses were able to group sugar and black maples on the basis of their geographical origins, they failed to do so on the basis of their morphologies. Furthermore, analyses using a larger number of RAPD polymorphisms failed to resolve black and sugar maples from a single, small collection site into separate clades (Fig. 2).

Thus, analyses of RAPD profiles generated from black and sugar maples collected throughout their ranges indicate that trees with these very distinctive morphologies are not genetically isolated. Despite their different adaptive advantages (Desmarais, 1952; Kriebel, 1957; Graves, 1994b), extensive hybridization of these trees where their ranges overlap appears to have made their respective gene pools indistinguishable. The implied absence of a substantive barrier to gene flow undermines the basis for assigning separate species designations to trees with the nigrum and saccharum morphologies. The morphological differences between these maples may be caused by environmental stimuli (Desmarias, 1952) or may simply reflect the extremes of a range of phenotypes governed by a relatively small number of genes.

When hybridization between $A$. nigrum and $A$. saccharum trees does occur, the traits characteristic of $A$. saccharum have been observed to be marginally dominant (Dansereau \& Desmarais, 1947) and this has resulted in concern regarding the possible loss of a true-breeding, naturally occurring $A$. nigrum stock in North America. The extent to which these morphologies have been naturally maintained 
despite homogenizing gene flow between them since (and perhaps, during) the last ice age makes such concerns appear to be unfounded.

\section{Acknow ledgements}

The authors thank James Runkle for his comments on the manuscript and help in collecting specimens from Ohio. The authors also thank William Graves, Susan Wiegrefe, Timothy Campbell and Neil Snow for their help in collecting specimens used in this study. This work was supported in part by a grant from the Ohio Biological Survey.

\section{References}

BURNS, R. M. AND HONKALA, B. H. 1990. Silvics of North America, vol. 2, Hardwoods. Agr. Hndbk. no. 654 Forest Service, United States Department of Agriculture. Washington, DC.

ClARK, A. G. AND LANIGAN, C. M. S. 1993. Prospects for estimating nucleotide divergence times with RAPDs. Mol. Biol. Evol., 10, 1096-1111.

DANSEREAU, P. AND DESMARAIS, Y. 1947. Introgression in Sugar Maples II. Am. Midl. Nat., 37, 146-161.

DESMARAIS, Y. 1952. Dynamics of leaf variation in the sugar maples. Brittonia, 7, 347-388.

DIRR, M. A. 1990. Manual of Woody Plants: Their Identification, Ornamental Characteristics, Culture, Propagation and Uses, 4th edn. Stipes, Champaign, IL.

FERRARIS, J. D. AND PALUMBI, S. R. 1996. Molecular Zoology: Advances, Strategies and Protocols. Wiley-Liss, New York.

FORÉ, S. A., HICKEY, R. J., GUTTMAN, S. I. AND VANKAT, J. L. 1992a. Temporal differences in genetic diversity and structure of sugar maple in an old-growth forest. Can. J. Forest Res., 22, 1504-1509.

FORÉ, S. A., HICKEY, R. J., VANKAT, J. L., GUTTMAN, S. I. AND SCHAFFER, R. L. 1992b. Genetic structure after forest fragmentation: a landscape ecology perspective on Acer saccharum. Can. J. Bot., 70, 1659-1668.

GEBUREK, T. 1993. Are genes randomly distributed over space in mature populations of sugar maple (Acer saccharum Marsh.)? Ann. Bot., 71, 217-222.

Grant, v. 1981. Plant Speciation, 2nd edn. Columbia University Press, New York.

graves, w. R. 1994a. Acer saccharum ssp. nigrum. Amer. Nuseryman, 179, 130.

GRAVES, W. R. 1994b. Seedling development of sugar maple and black maple irrigated at various frequencies. HortScience, 29, 1292-1294.

HAMELIN, R., OUELlETTE, G. AND BERNIER, L. 1993. Identification of Gremmeniella-Ablentina races with random amplified polymorphic DNA markers. App. Environ. Microbiol., 59, 1752-1755.

isABel, N., BeAulieu, J. AND Bousquet, J. 1995. Complete congruence between gene diversity estimates derived from genotypic data at enzyme and random amplified polymorphic DNA loci in black spruce. Proc. Natl. Acad. Sci. U.S.A., 92, 6369-6373.

KRIEBEL, H. B. 1957. Patterns of genetic variation in sugar maple. Ohio Agr. Exp. Stn. Res. Bulletin 791, Wooster, $\mathrm{OH}$.

KRIEBEL, H. B. AND GABRIEL, W. J. 1969. Genetics of sugar maple. USDA, Forest Service Research Paper. WO-7, 21, 1-17.

LitTLE, E. L. 1979. Checklist of United States Trees (Native and naturalized). Forest Service, United States Department of Agriculture Agr. Hndbk. no. 541, Washington, DC.

MADDISON, w. P. AND MADDISON, D. R. 1992. MacClade, Analysis of Phylogeny and Character Evolution, Ver. 3. Sinauer Associates, Sunderland, MA.

NEI, M. 1987. Molecular Evolutionary Genetics. Columbia University Press, New York.

N'GORAN, J. A. K., LAURENT, V., RISTERUCCI, A. M. AND LANAUD, C. 1994. Comparative genetic diversity studies of Theobroma cacao L. using RFLP and RAPD markers. Heredity, 73, 589-597.

PERRY, D. J. AND KNOWLES, P. 1990. Spatial genetic structure within three sugar maple (Acer saccharum) stands. Heredity, 66, 137-142.

ROHLF, F. J. 1994. NT-SYS-pc. Numerical taxonomy and multivariate analysis system. Version 1.80. Exeter Software, Setauket, NY.

Simon, J., PAYeTte, Y. AND LONGPRE, M. 1995. Comparative analysis of the genetic composition of canopy and juvenile sugar maple individuals (Acer saccharum) in an old growth forest in southern Quebec as related to anthropogenic disturbance. Can. J. Forest Res., 25, $743-752$.

SOlOMON, A. M. 1983. Pollen morphology and plant taxonomy of white oaks in eastern North America. Am. J. Bot., 70, 481-494.

STEINDEl, M., NETO, E. D., PINT, C. J. C., GRISARD, E. C., MENEZES, C. L. P., MURTA, S. M. F. ET AL. 1994. Randomly Amplified Polymorphic DNA (RAPD) and isoenzyme analysis of Trypanosoma rangeli strains. J. Euk. Microbiol., 41, 261-267.

SWOFFORD, D. L. 1991. PAUP. Phylogenetic analysis using parsimony. Version 3.0r. Illinois Natural History Survey, Champaign, IL.

WHITTEMORE, A. T. AND SCHAAL, B. A. 1991. Interspecific gene flow in sympatric oaks. Proc. Natl. Acad. Sci. U.S.A., 88, 2540-2544.

WILLIAMS, J. G. K., KUBELIK, A. R., LIVAK, K. J., RAFALSKI, J. A. AND TINGEY, S. v. 1990. DNA polymorphisms amplified by arbitrary primers are useful as genetic markers. Nucl. Acids Res., 18, 6531-6535.

YOUNG, A. G., WARWICK, S. I. AND MERRIAM, H. G. 1993. Genetic variation and structure at three spatial scales for Acer saccharum (sugar maple) in Canada and the implications for conservation. Can. J. Forest Res., 23, 2568-2578. 